Biochem. Lett., Vol. 7, PP.91-118 (2012)

\title{
MODULATION OF STAT 5A SIGNAL TRANSDUCTION IN BREAST CANCER CELL LINES RESTORE MESENCHYMAL-EPITHELIAL TRANSITION
}

\author{
Ahmed S. Sultan \\ Department of Biochemistry, Faculty of Science, Alexandria \\ University, Alexandria 21511, Egypt, Department of Oncology, \\ Georgetown University Medical Center, Washington DC, 20057, USA
}

\begin{abstract}
Glucocorticoids have demonstrated value in the adjuvant treatment of breast cancer, although only approximately 25\% of patients respond to glucocorticoid treatment alone. Better understanding of the molecular mechanisms underlying the therapeutic responses of breast cancer to glucocorticoid treatment may lead to new selection criteria and improve response rates. Experimental evidence in rodents has indicated that glucocorticoid treatment protects against the mammary tumor promoting effect of prolactin, and a molecular interaction between glucocorticoids and prolactin downstream of prolactin receptor activation has been suggested. Recently, we have discovered a new role of Stat5a as tumor suppression gene for breast cancer invasion that inhibited breast cancer stem cell characteristics in primary tumor and human cell lines. We now report that dexamethasone can up-regulate prolactin signaling via Stat5a in certain human breast cancer cell lines. Pretreatment of the human breast cancer cell line T47D for 2-4 days led to marked enhancement of prolactin activation of the transcription factor Stat5a. Thus, dexamethasone induced a qualitative change in prolactin signals from exclusive Stat5b activation to combined recruitment of Stat5a and Stat5b, with extensive heterodimerization of the two transcription factors. This dexamethasone-dependent
\end{abstract}




\section{Modulation Of State 5A Activation And 14ET}

change in prolactin signals was associated with stimulation of terminal differentiation markers in T47D cells. Interestingly, prolactin activation of mitogen-activated protein kinases and growth-related genes c-fos, $c$-jun and c-myc was not affected by dexamethasone. A similar, but less marked, stimulation by dexamethasone pretreatment of prolactin-activated Stat5a was seen in MCF-7 cells. In contrast, Stat5a expression was lost in the undifferentiated, estrogen receptor (ER)-negative BT-20 and SKBr3 cell lines, and could not be rescued by dexamethasone. In the nearnormal mammary cell lines, HC11 and MCF-10A, equal levels of Stat5a and Stat5b were expressed in a dexamethasone-independent manner. These studies identify Stat5a as a target for dexamethasone regulation with potential importance for inhibition of tumor metastasis and restore mesenchymal-epithelial transition (MET) of certain mammary cancers, and may help explain the variable response rate of breast cancer patients to glucocorticoid treatment.

\section{INTRODUCTION}

Glucocorticoid hormones are frequently included in various regimens of combination chemotherapy of breast cancer, and have a beneficial effect on overall survival time ${ }^{(1-3)}$ A trial of radiation treatment plus or minus prednisone found that radiation and prednisone together had a significant increase over radiation alone in disease-free interval and overall survival in premenopausal women over age $45^{(4)}$, but were not beneficial in postmenopausal women ${ }^{(5,6)}$. Overall, treatment of breast cancer with glucocorticoids alone resulted in a moderate response rate of approximately $25 \%{ }^{(7)}$, suggesting that a subpopulation of these cancers are glucocorticoid-sensitive. Little is known about the molecular mechanisms underlying the therapeutic responses of breast cancer to dexamethasone treatment ${ }^{(8)}$. However, several experimental rodent model systems have suggested that glucocorticoids protect against the mammary tumor promoting effect of prolactin $(9,10)$. Suppression of prolactin-induced mammary tumor growth by glucocorticoids appears to be direct and not mediated by inhibition of pituitary prolactin secretion or by a reduction in 


\section{Ahmed S. Sultan}

mammary cell prolactin receptors ${ }^{(10)}$, suggesting a molecular interaction between glucocorticoids and prolactin downstream of prolactin receptor activation.

Prolactin has been shown unequivocally to be a tumor promoter of the mammary gland by a variety of experimental approaches in rodents, including prolactin over-expressing transgenic mice ${ }^{(11-14)}$. The role of prolactin in the etiology and progression of breast cancer in humans has been controversial mainly due to the lack of a simple correlation between circulating prolactin levels and breast cancer incidence ${ }^{(15-20)}$, and that pharmacological suppression of pituitary prolactin secretion has had inconsistent impact on tumor growth (21-22). However, several laboratories have detected local production of prolactin in rodent and human mammary epithelium and human breast carcinomas, and accumulating evidence suggests that prolactin can act as an autocrine mammary growth factor ${ }^{(14,23-26)}$. Consistent with a local growth stimulatory role of prolactin on mammary epithelial cells, prolactin receptor antagonists inhibited the growth of several human breast tumor cell lines cultured in the absence of exogenous lactogenic hormones ${ }^{(27)}$. Furthermore, $40-70 \%$ of human breast tumor biopsies are positive for prolactin receptors ${ }^{(22,}$ 28), and many tumor-derived cell lines express increased levels of prolactin receptors and can proliferate in response to prolactin in vitro ${ }^{29-33)}$. However, in the appropriate hormonal milieu, particularly in the presence of glucocorticoids, prolactin becomes a differentiation factor for mammary cells ${ }^{(34-36)}$. It is therefore possible that the beneficial effects of glucocorticoids in a subpopulation of breast cancer patients is due to a modulation of prolactin signal transduction.

Prolactin activates the Jak2-Stat5 pathway ${ }^{(37-39)}$ and the RasMitogen-activated protein kinase (MAPK) pathway ${ }^{(40,41)}$. Whereas the mitogenic effects of prolactin have been attributed to the RasMAPK signaling pathway (42-44), prolactin-induced terminal differentiation of mammary epithelium and milk protein expression (e.g., $\beta$-casein, $\beta$-lactoglobulin and prolactin-inducible protein) appear to be mediated by activation of Stat5 transcription factors (45-47), particularly Stat5a ${ }^{(48)}$. Recent studies in reconstituted COS-7 cells have suggested that glucocorticoids facilitate prolactin signaling via 


\section{Modulation Of State 5A Activation And 14ET}

Stat5 directly at the level of the $\beta$-casein gene promoter, and accumulating evidence supports the concept that the glucocorticoid receptor is a ligand-activated coactivator of Stat5 transcription factors (49-52). Despite the direct interaction between the glucocorticoid receptor and Stat5 molecules described in COS-7 cells, several days of pretreatment with glucocorticoid hormones is needed to detect an enhancement of prolactin-induced differentiation markers in mammary cells ${ }^{(52)}$, suggesting additional levels of cooperation between glucocorticoids and prolactin. Recently, we shed a light on a new role of Stat5a as tumor suppressor gene that inhibits breast cancer invasion and breast cancer stem cell characteristics in human breast cancer $^{(53,54)}$.

We now report that dexamethasone can up-regulate prolactin signaling via Stat5a in certain human breast cancer cell lines. Pretreatment of T47D cells for 2-4 days led to marked enhancement of prolactin activation of the transcription factor Stat5a. Thus, dexamethasone induced a qualitative change in prolactin signals from exclusive Stat5b activation to combined recruitment of Stat5a and Stat5b, with extensive heterodimerization of the two transcription factors. This dexamethasone-dependent change in prolactin signals was associated with prolactin stimulation of terminal differentiation markers in T47D cells. Interestingly, prolactin activation of MAPK and growth-related genes c-fos, c-jun and c-myc was not affected by dexamethasone. A similar, but less marked, stimulation by dexamethasone pretreatment of prolactin-activated Stat5a was seen in MCF-7 cells. On the other hand, the two near-normal mammary cell lines, murine $\mathrm{HC} 11$ cells and human MCF-10A cells, expressed equal levels of Stat5a and Stat5b in a dexamethasone-independent manner. Importantly, Stat5a expression was both lost and not inducible by dexamethasone in the undifferentiated, estrogen receptor (ER)negative BT-20 and SKBr3 cell lines. These studies identify Stat5a as a target for dexamethasone regulation of potential importance for differentiation therapy of certain mammary cancers, and may help explain the variable response rate of breast cancer patients to glucocorticoid treatment. 


\section{MATERIALS AND METHODS}

Materials: Ovine prolactin (NIDDK-oPRL-19, AFP-9221A) and human prolactin (NIDDK-hPRL-SIAFP-B2, AFP-2969A) were supplied by the National Hormone and Pituitary Program, National Institute of Diabetes and Digestive and Kidney Diseases (Baltimore, $\mathrm{MD})$. Dexamethasone, insulin and cholera toxin were purchased from Sigma (cat. nos. D8893, I5500 and C3012, respectively). Epidermal growth factor was obtained from Peprotech (cat. no. 100-15). Polyclonal rabbit antisera specific to peptides corresponding to the unique $\mathrm{COOH}$-termini of Stat1 $\alpha$, Stat3, Stat5a and Stat5b were generated as described previously (56). Monoclonal antiphosphotyrosine antibody 4G10 and anti-human casein were purchased from UBI (cat. no. 06-321) and Harlan Sera-Lab (cat. no. MAS, 447p), respectively. Rabbit antibodies to active mitogenactivated protein kinase (MAPK) were purchased from Promega (cat. no. V667A), and a mouse monoclonal anti-panERK antibody was obtained from Transduction Laboratories (cat. no. E17120/L3). Horseradish peroxidase-conjugated goat antibodies to mouse or rabbit IgG were purchased from Kirkegaard and Perry Laboratories (cat. nos. 074-1806 and 074-1506, respectively).

Cell Culture: Human breast cancer cell lines were obtained from ATCC (Rockville, MD), including MCF-10A (cat. no. CRL10317), MCF-7 (cat. no. HTB 22), T47D (cat. no. HTB 133), SKBr3 (cat. no. HTB 30) and BT-20 (cat. no. HTB 19). The HC11 cell was a gift from Dr. Gibbs Johnson (Food and Drug Administration, Bethesda, MD). Cells were grown in RPMI-1640 medium (Mediatech, cat. no. 15-040-LM) containing 10\% fetal calf serum (Intergen, cat. no. 1020-90), 2 mM L-glutamine (Mediatech, cat. no. 25-040-LI; 50 $\mathrm{IU} / \mathrm{ml}$ ), penicillin-streptomycin (Mediatech, cat. no. 30-040-LI; 5

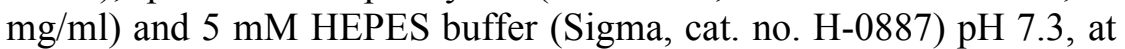
37 C with $5 \% \mathrm{CO}_{2}$. HC11 cells were cultured in complete RPMI1640 medium supplemented with $5 \mu \mathrm{g} / \mathrm{ml}$ insulin and $10 \mathrm{ng} / \mathrm{ml}$ EGF. MCF-10A cells were similarly supplemented with $10 \mu \mathrm{g} / \mathrm{ml}$ insulin, $0.1 \mu \mathrm{g} / \mathrm{ml}$ cholera toxin, and $(20 \mathrm{nM})$ dexamethasone. 


\section{Modulation Of State 5A Activation And 14ET}

Induction and Detection of Casein: T47D cells were grown to confluence in growth medium, then maintained in serum-free medium with or without prolactin $(10 \mathrm{nM})$, dexamethasone $(1 \mu \mathrm{M})$ and/or insulin $(5 \mu \mathrm{g} / \mathrm{ml})$ for four days. The cells were harvested by scraping in ice-cold phosphate buffered saline (PBS), $\mathrm{pH}$ 7.4, pelleted by centrifugation, and lysed in $1 \mathrm{ml}$ of lysis buffer containing $10 \mathrm{mM}$ Tris-HCl, $\mathrm{pH}$ 7.6, $5 \mathrm{mM}$ EDTA, $50 \mathrm{mM} \mathrm{NaCl}$, 1\% Triton X-100, 1 $\mathrm{mM}$ phenylmethylsulfonyl fluoride (PMSF), $5 \mu \mathrm{g} / \mathrm{ml}$ aprotinin, 1 $\mu \mathrm{g} / \mathrm{ml}$ pepstatin A and $2 \mu \mathrm{g} / \mathrm{ml}$ leupeptin. The lysates were clarified by centrifugation and $50 \mu \mathrm{g}$ of total protein per sample separated by $12 \%$ SDS-PAGE. The proteins were then transferred to polyvinylidene difluoride (PVDF) membrane (Millipore, cat. no. 1PVH 00010), using a semi-dry transfer unit (Multiphor Novablot, Pharmacia) at constant current of $195 \mathrm{~mA}$ for $80 \mathrm{~min}$. After transfer, the blots were incubated for at least $1 \mathrm{~h}$ at room temperature in blocking buffer $(0.02 \mathrm{M}$ Tris-HCl, $\mathrm{pH} 7.6,0.137 \mathrm{M} \mathrm{NaCl}, 1 \%$ bovine serum albumin, and $0.01 \%$ sodium azide) before immunoblotting. Blots were exposed for $30 \mathrm{~min}$ to anti-human casein antiserum diluted 1:1000 in blocking buffer. The blots were then incubated twice for 5 min in wash buffer (50 mM Tris- $\mathrm{HCl}, \mathrm{pH} 7.6,200 \mathrm{mM} \mathrm{NaCl}, 0.25 \%$ Tween 20), followed by incubation for $30 \mathrm{~min}$ with horseradish peroxidase-conjugated goat antibodies to mouse $\operatorname{IgG}$ at $500 \mathrm{ng} / \mathrm{ml}$ in blocking buffer, followed by four $15 \mathrm{~min}$ incubations in wash buffer. The blots were then incubated for $1 \mathrm{~min}$ with enhanced chemiluminescence substrate (ECL) mixture according to the manufacturer's instructions (Amersham, cat. no. RPN2106), and exposed to BioMax film for 1-5 min (Kodak, cat. no. 165 1454).

Dexamethasone Induction and Prolactin Stimulation: Breast cancer cells were grown to confluence and subsequently incubated in serum-free medium with or without dexamethasone $(1 \mu \mathrm{M})$ for the length of time indicated (time-course experiment) or for four days (all other experiments). Cells were then stimulated for $15 \mathrm{~min}$ with ovine prolactin $(10 \mathrm{nM}, \mathrm{HC} 11$ cells $)$ or with human prolactin $(10 \mathrm{nM}$, all other cell lines) and harvested by scraping in ice-cold phosphate buffered saline (PBS), $\mathrm{pH}$ 7.4, containing $15 \mathrm{mM}$ sodium 
pyrophosphate, $25 \mathrm{mM}$ sodium fluoride and $0.1 \mathrm{mM}$ sodium orthovanadate. The cells were pelleted by centrifugation and immediately frozen in dry ice/methanol.

Solubilization of Proteins and Immunoprecipitation: Frozen pellets from $10^{8}$ breast cancer cells were thawed on ice and solubilized in $1 \mathrm{ml}$ of lysis buffer containing $10 \mathrm{mM}$ Tris- $\mathrm{HCl}, \mathrm{pH} \mathrm{7.6,5 \textrm {mM }}$ EDTA, $50 \mathrm{mM} \mathrm{NaCl}, 30 \mathrm{mM}$ sodium pyrophosphate, $50 \mathrm{mM}$ sodium fluoride, $1 \mathrm{mM}$ sodium orthovanadate, $1 \%$ Triton X-100, $1 \mathrm{mM}$ phenylmethylsulfonyl fluoride (PMSF), $5 \mu \mathrm{g} / \mathrm{ml}$ aprotinin, $1 \mu \mathrm{g} / \mathrm{ml}$ pepstatin A and $2 \mu \mathrm{g} / \mathrm{ml}$ leupeptin. Cell lysates were rotated end over end at $4^{\circ} \mathrm{C}$ for $60 \mathrm{~min}$, and insoluble material was pelleted at $12,000 \mathrm{x}$ $g$ for $30 \mathrm{~min}$ at $4 \cong \mathrm{C}$. Clarified lysates were incubated rotating end over end for $3 \mathrm{~h}$ at $4^{\circ} \mathrm{C}$ with polyclonal rabbit antisera $(2 \mu \mathrm{l} / \mathrm{ml})$ to individual proteins as specified. Antibodies were captured by incubation for $60 \mathrm{~min}$ with protein A-Sepharose beads (Pharmacia Biotech, cat. no. 17-0780-01), followed by three washes in lysis buffer. Precipitated material was eluted off the beads by addition of 75 $\mu \mathrm{l}$ of $2 \mathrm{X}$ SDS-sample buffer $(0.125 \mathrm{M}$ Tris-HCl, $\mathrm{pH} 6.8,20 \%$ glycerol, $10 \%$ 2-mercaptoethanol, $4.6 \% \quad \mathrm{SDS}$, and $0.0004 \%$ bromophenol blue) followed by heating to $95 \cong \mathrm{C}$ for $10 \mathrm{~min}$. Samples were subjected to $7.5 \%$ SDS-PAGE under reducing conditions according to Laemmli ${ }^{(58)}$. The proteins were then transferred to PVDF as described above.

Immunoblot Analysis: Blots were exposed for $90 \mathrm{~min}$ to primary antibodies diluted in blocking buffer at the following concentrations: antiphosphotyrosine mAb 4G10 ( $1 \mu \mathrm{g} / \mathrm{ml}) ; \alpha$-Stat5a and $\alpha-$ Stat5b antisera (1:3000). The blots were then incubated twice for $5 \mathrm{~min}$ in wash buffer $(50 \mathrm{mM}$ Tris- $\mathrm{HCl}, \mathrm{pH} 7.6,200 \mathrm{mM} \mathrm{NaCl}$, $0.25 \%$ Tween 20 ), followed by incubation for $30 \mathrm{~min}$ with horseradish peroxidase-conjugated goat antibodies to mouse or rabbit IgG at 500 $\mathrm{ng} / \mathrm{ml}$ in blocking buffer, followed by four $15 \mathrm{~min}$ incubations in wash buffer. The proteins were visualized by ECL, as described above. When required, blots were stripped for $30 \mathrm{~min}$ at $60^{\circ} \mathrm{C}$ in buffer containing $62.5 \mathrm{mM}$ Tris-HCl (pH 6.8), 2\% SDS and $100 \mathrm{mM} \beta$ mercaptoethanol, and were blocked for $2 \mathrm{~h}$ before reblotting. 


\section{Modulation Of State 5A Activation And 14ET}

\section{RESULTS}

Dexamethasone stimulates a differentiation response to prolactin in human T47D breast cancer cells. It is well established that the hormones prolactin, hydrocortisone and insulin cooperate in the regulation of milk protein synthesis and differentiation of mammary explants and normal mammary epithelial lines $(36,58)$. However, little is known about the precise mechanism underlying the differentiating effect of glucocorticoids in human mammary cancer cells ${ }^{(8,59)}$. We first examined the ability of glucocorticoids to influence prolactin-induced differentiation of the well-characterized human mammary cancer cell line, T47D. Originally derived from a patient with a moderately differentiated infiltrating ductal carcinoma, T47D cells express receptors for estrogen, progesterone, glucocorticoids, and prolactin ${ }^{(60)}$. Insulin was also included in these initial experiments due to its reported promotion of mammary differentiation.

When confluent monolayers of T47D cells were preincubated under serum-free conditions in the presence or absence of dexamethasone $(1 \mu \mathrm{M})$, prolactin $(10 \mathrm{nM})$ and/or insulin $(5 \mu \mathrm{g} / \mathrm{ml})$ for $48 \mathrm{~h}$, a marked increase in expression of the milk protein, casein, was detected by immunoblotting in response to prolactin in the dexamethasone-pretreated cells (fig. 1A). Insulin pretreatment alone

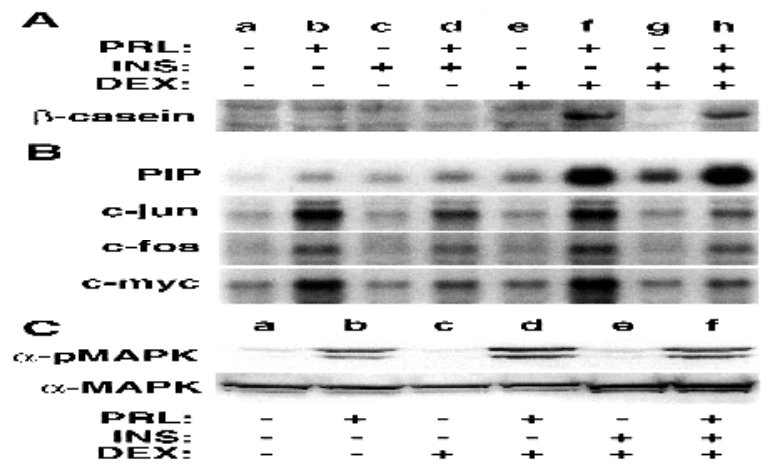

Figure 1. Dexamethasone is critical for prolactin-induced 
had no effect on prolactin-induced casein induction, and coadministration of insulin did not modulate the positive effect of dexamethasone (fig. 1A, lanes $\mathrm{f}$ and $\mathrm{h}$ ). A similar pattern was observed of dexamethasone-dependent and insulin-independent stimulation of prolactin-induced mRNA levels of another secretory protein, gross cystic disease fluid protein-15 (fig. 1B, panel 1), also known as prolactin-inducible protein (PIP). Originally characterized as a prolactin-responsive gene in the mammary gland and other exocrine glands $(30,61)$, PIP expression has also been shown to correlate positively with mammary tumor differentiation ${ }^{(62,63)}$. In contrast to the positive effect of dexamethasone on prolactin-induced differentiaition markers, dexamethasone pretreatment did not modulate prolactin-induction of mRNA levels for the growth-related genes c-fos, c-jun and c-myc (fig. 1B, panels 2-4). On the other hand, insulin pretreatment alone or in combination with dexamethasone appeared to reduce the prolactin-induced mRNA levels of these growth-related transcription factors (fig. 1B, panels 2-4, lanes c and h).

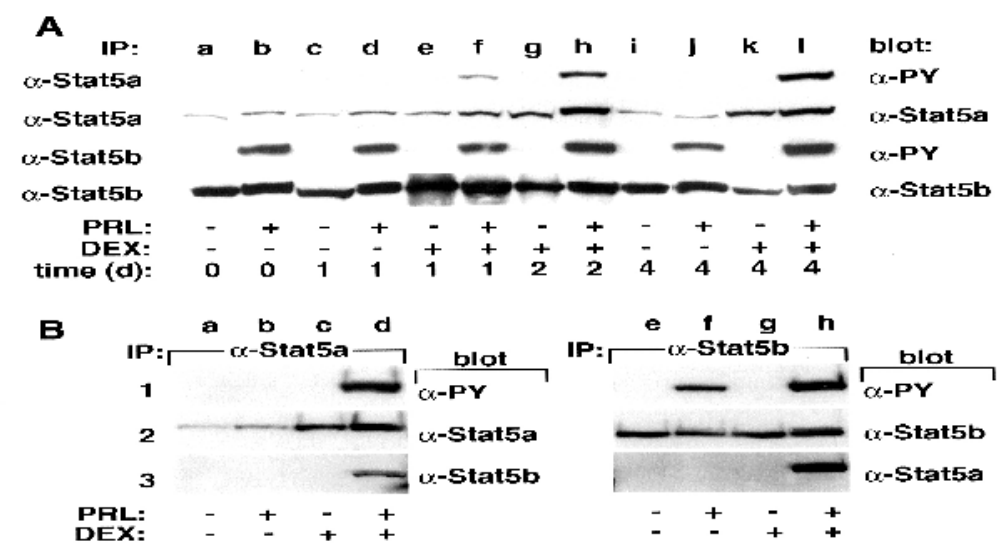

Figure 2. Dexamethasone upregulates prolactin activation of Stat5a in T47D cells and induces prolactin -induced Stat5a-Stat5b heterodimers. 


\section{Modulation Of State 5A Activation And 14ET}

differentiation responses in human T47D breast cancer cells, but does not affect prolactin-induced growth signals.

We also examined the effect of dexamethasone pretreatment on prolactin- activation of MAPK, since prolactin has been specifically suggested to stimulate growth of T47D cells via the Ras-MAPK pathway ${ }^{(42,44)}$. As was the case for prolactin-induced proto-oncogene expression, $48 \mathrm{~h}$ of pretreatment with dexamethasone under serumfree conditions did not significantly affect prolactin-induced MAPK activation or the expression of the ERK1 and ERK2 serine kinases (fig. 1C). Pretreatment with insulin and dexamethasone also did not influence prolactin-activation of MAPK, although this combination appeared to moderately elevate the expression levels of ERK1 and ERK2.

From this initial set of data we concluded that pretreatment of the human breast cancer cell line T47D with dexamethasone had a marked stimulatory effect on prolactin induction of the differentiation markers casein and PIP, but did not modulate putative growth signals via MAPK or transcription factors c-jun, c-fos or c-myc. Insulin appeared to be of lesser importance for prolactin induction of differentiation markers than what has been previously reported for normal mammary cells (64). Since Stat5 transcription factors are putative mediators of prolactin-induced differentiation in the mammary gland (45-48), we specifically examined whether dexamethasone modulated prolactin activation of the Stat5a and Stat5b transcription factors.

Pretreatment of T47D cells with dexamethasone upregulates prolactin-induced activation of Stat5a and leads to formation of Stat5a-Stat5b heterodimers. We have previously described prolactin-induced activation of Stat5 in T47D cells ${ }^{(54,55)}$. However, more detailed analysis revealed that this was a selective Stat5b activation with little or no Stat5a activation ${ }^{(65)}$, suggesting the possible loss of a mediator of differentiation in these cells. This is in contrast to other prolactin target cells thus far examined, in which prolactin activates Stat5a and Stat5b equally well, including lymphoid $\mathrm{Nb} 2$ cells, HC11 mammary epithelial cells, prolactin receptor 
expressing 32D myeloid cells and $\mathrm{Ba} / \mathrm{F} 3$ lymphoid cells $(36,55)$. Although both Stat5a and Stat5b transcription factors are able to mediate prolactin-induced $\beta$-casein transcription when expressed individually in COS-7 cells, mammary development and differentiation is significantly more impaired in Stat5a knockout mice than in Stat5b deficient mice which are able to lactate $(48,66)$.

We first examined the effect of dexamethasone pretreatment on the extent of prolactin-induced tyrosine phosphorylation of Stat5a and Stat5b and their expression levels. Preliminary experiments showed that a preincubation period of between 48 and 96 hours was required for dexamethasone to facilitate prolactin stimulation of differentiation markers in T47D cells (data not shown). Confluent T47D cells were treated with or without dexamethasone for varying times up to 4 days in the absence of serum, and were then stimulated with prolactin for $15 \mathrm{~min}$ before analysis by immunoprecipitation and immunoblotting (fig. 2A). As previously noted, in T47D cells that had not been pretreated with dexamethasone (panels 1 and 3; lanes a and b), prolactin selectively activated Stat5b with little or no activation of Stat5a. However, over 4 days of pretreatment, dexamethasone had a marked stimulatory effect on prolactin-induced Stat5a tyrosine phosphorylation (panel 1). The basal expression of Stat5a was also significantly elevated from very low levels (panel 2) to amounts approximately equal to the those of Stat5b (panel 4). There was no significant induction of Stat5b expression or tyrosine phosphorylation by dexamethasone treatment, leading to prolactin-induced formation of significant amounts of Stat5a-Stat5b heterodimers, as visualized by reciprocal coimmunoprecipitation of Stat5a and Stat5b from cells treated with dexamethasone followed by prolactin (fig. 2B, panel 3).

Although it remains to be established whether this qualitative shift in the pattern of Stat5 isoform activation alters the gene expression control by prolactin receptors, the observation that mammary gland differentiation is more affected in Stat5a-deficient mice than in Stat5b-deficient mice ${ }^{(48,66)}$ has suggested that these two homologous proteins are functionally different. The observed induction by dexamethasone of Stat5a activation by prolactin in T47D cells thus indicated an unrecognized form of cooperation between 


\section{Modulation Of State 5A Activation And 14ET}

glucocorticoid and prolactin at the level of Stat5a expression and recruitment.

Finally, it should be emphasized that the observed positive interaction between extended glucocorticoid treatment and short-term prolactin receptor activation at the level of phosphorylation of Stat5 proteins complements the reported direct interaction between glucocorticoids and prolactin at the transcriptional level, and does not contradict the concept that glucocorticoid receptors also act as liganddependent co-activators of Stat5 transcription factors $(51,65,71)$.

\section{DISCUSSION}

Recently, we discovered a new role of Stat5a as tumor suppressor gene and inhibitors to EMT progression and breast cancer stem cell characteristics primary tumors and cell lines ${ }^{(53,54)} \mathrm{Up}$ regulation of active Stat5a is a new strategy to inhibit human breast cancer invasion and metastasis for human breast cancer, especially we data showed that Stat5a activation is lost in metastatic human breast cancer. The present study provides novel evidence that glucocorticoids can regulate prolactin activation of Stat5a and thus modulate the extent of prolactin-induced differentiation of mammary cancer cells, and in turn inhibited breast cancer invasion capacity. Pretreatment of the human breast cancer cell line T47D with dexamethasone for 2-4 days was required for prolactin to activate Stat5a as evidenced by a marked up-regulation of prolactin-induced Stat5a tyrosine phosphorylation and Stat5a-Stat5b heterodimer formation. This modulation of prolactin signal transduction correlated with induction of differentiation markers casein and PIP. A similar but less marked stimulation by dexamethasone pretreatment of prolactinactivated Stat5a was seen in MCF-7 cells. Furthermore, Stat5a expression was lost in the undifferentiated, ER-negative BT-20 and SKBr3 cell lines and could not be rescued by dexamethasone treatment. In contrast, the well-differentiated, near-normal mammary 
cell lines MCF-10A and HC11 expressed comparably high levels of both Stat5a and Stat5b. These studies therefore identify Stat5a as a target for dexamethasone regulation of prolactin signal transduction, a finding that has potential importance for differentiation therapy of mammary cancers, and implicate Stat5a as a candidate differentiation marker of possible prognostic importance for human breast cancer progression.

Prolactin has been shown to activate several members of the Stat transcription factor family, including Stat1, Stat3, Stat5a and Stat5b ${ }^{(38,54,65,72)}$. Of these, Stat5a and Stat5b bind strongly to the prolactin response element of the $\beta$-casein gene, whereas Stat1 and Stat3 have shown little or no ability to bind to the promoter region of this milk protein gene ${ }^{(65)}$. Although both Stat5a and Stat5b bind to and activate transcription of $\beta$-casein reporter genes in COS-7 cells ${ }^{(50,}$ 73, 74), Stat5a has been thought to be particularly important for mammary gland differentiation. Stat5a-deficient female mice have a severe phenotypic loss of prolactin-induced milk production (48), whereas the phenotype of corresponding Stat5b knockout mice is characterized by specific growth hormone signaling defects, resulting in stunted growth and liver dysfunction with less impact on milk production (66).

The finding in the present study that prolactin activation of Stat5a is regulated by dexamethasone in some, but not all human breast cancers, has direct implications for differentiation therapy of human breast cancer. The data suggest that in normal cells, Stat5a is operable and available to prolactin receptors; in moderately differentiated cancer cell lines (MCF-7, T47D), dexamethasone treatment is able to stimulate prolactin induced Stat5a activation; and, in the more malignant, ER-negative SKBr3 and BT-20 cell lines, prolactin-induced tyrosine phosphorylation of Stat5a is refractory to dexamethasone treatment. The current observations provide incentive for more general and systematic screening efforts of breast tumors for Stat5 activation patterns. With respect to the involvement of prolactin in the development of mammary gland neoplasia, these findings also call for reconsideration of the substantial biologic evidence that 


\section{Modulation Of State 5A Activation And 14ET}

prolactin can serve either as a mammary epithelium growth promoter or as a cytostatic differentiation agent ${ }^{(75-77) \text {. }}$

This dual capacity of prolactin to induce either cellular proliferation or differentiation of mammary cells suggests the presence of thus far uncharacterized physiological regulatory mechanisms that can control response switching at the cellular level. Implicit in this notion, that prolactin-induced responses are dependent on physiological conditions (e.g. cell specific factors, hormones or developmental maturation) is the concept that prolactin might function as tumor promoter only when the physiological environment or pathophysiologic changes favor prolactin receptor-mediated growth. Indeed, the prolonged controversy over the involvement of prolactin in human breast cancer etiology and progression might to a large extent be explained if circulating or autocrine prolactin proved to serve as a conditional mammary tumor promoter. A duality of prolactin actions might also illuminate why multiparity and prolonged suckling tend to lower breast cancer risk ${ }^{(78)}$. It would be reasonable to hypothesize that physiological conditions postpartum might yield a protective effect by fostering the differentiating effects of prolactin. Thus, a better understanding of how prolactin acts as a conditional growth factor or tumor promoter, or conversely as a differentiation agent, becomes a critical issue with strong relevance to the problem of growth factor-induced breast cancer development and growth factorbased therapeutic strategies. Similar dual roles as context-dependent growth or differentiation agents have been established for a variety of the other four-helix bundle polypeptide cytokines and hormones that activate JAK-Stat pathways via a related family of cell surface receptors, including oncostatin $\mathrm{M}$, leukemia-inhibitory factor, erythropoietin, and a majority of the interleukins ${ }^{(79)}$.

To what extent transcriptional regulation of Stat5-responsive genes varies with Stat5a and Stat5b dimerization patterns remains unknown. The two proteins differ most in the $\mathrm{COOH}$-terminal regions which are involved in docking of $\mathrm{SH} 2$ domains and transactivation. Stat5a and Stat5b can undergo homo- and heterodimerization, and bind to similar DNA response elements ${ }^{(56)}$. However, Stat5a and Stat5b may also form different complexes to DNA as revealed by 
EMSA ${ }^{(56)}$. The two transcription factors may therefore have both overlapping and distinct functions. Consistent with this notion, T-cell function is maintained in mice deficient in either Stat 5 a or Stat $5 b$ gene alone ${ }^{(48,66)}$, but is severely suppressed in mice deficient in both ${ }^{(80)}$. In contrast, Stat5b is unable to compensate for Stat5a-deficiency in female mice, resulting in phenotypic loss of prolactin-induced milk production ${ }^{(48)}$. Conversely, Stat5b knockout mice have specific growth hormone signaling defects, resulting in stunted growth and liver dysfunction (66). Other differences between Stat5a and Stat5b are demonstrated by differing degrees of serine phosphorylation in interleukin-2 stimulated lymphocytes (68). We have also found differential regulation of serine phosphorylation of Stat5a and Stat5b in prolactin sensitive cells (81). Therefore, a series of dissimilarities points toward certain unique control mechanisms and possibly specialized functions of Stat5a and Stat5b proteins. Systematic testing of a series of Stat5-regulated genes in addition to b-casein is needed to establish functional differences between Stat5a and Stat5b.

Regarding the role of Stat5 transcription factors in breast cancer, it is of particular interest to note that the Stat5a and Stat5b genes are localized to chromosome $17 \mathrm{q} 11.2^{(82)}$. Markers mapping to this locus have revealed loss of heterozygosity in $25-79 \%$ of human breast cancers ${ }^{(83)}$ consistent with the presence of tumor suppressor gene(s). The fact that the recently identified BRCA1 gene is also localized to this arm of chromosome $17^{(84,85)}$ does not rule out the existence of additional tumor suppressor genes nearby. As a differentiation factor that may counterbalance the growth promoting effect of prolactin in the mammary gland, transcription factor Stat5a is indeed a candidate mammary tumor suppressor, and future studies will specifically examine the frequency of loss of Stat5a gene expression in human breast cancer.

In summary, we present novel evidence that glucocorticoids can regulate prolactin activation of Stat5a and thus modulate the extent of prolactin-induced differentiation of mammary cancer cells. Furthermore, Stat5a expression was lost in the undifferentiated, ERnegative BT-20 and SKBr3 cell lines and could not be rescued by dexamethasone treatment, whereas well-differentiated, near-normal 


\section{Modulation Of State 5A Activation And 14ET}

mammary cell lines MCF-10A and HC11 expressed comparably high levels of both Stat5a and Stat5b. These studies therefore implicate Stat5a as a critical differentiation factor of potential importance for glucocorticoid therapy against a subgroup of mammary cancers.

\section{ACKNOWLEDGMENTS}

This work has been supported by Susan G. Komen Breast Cancer Foundation grant \# BCTR0504208 to Ahmed S. Sultan.

\section{REFERENCES}

1-Stewart, J.F.; Rubens R.D.; King, R.J.; Minton, M. J.; Steiner, R.; Tong, D.; Winter, P. J.; Knight,R.K.; Hayward,J.L. (1982): Contribution of prednisolone to the primary endocrine treatment of advanced breast cancer. Eur. J. Cancer Clin. Oncol. 18: 1307-1314.

2-Jones, S.E.; Salmon, S,E, (1984): Eastern Cooperative Oncology Group. Adjuvant systemic therapy in premenopausal (CMF, CMFP, CMFPT) and postmenopausal (observation, CMFP, CMFPT) women with node positive breast cancer. Adjuvant Therapy of Cancer IV, pp. 359-368. Orlando: Grune and Stratton.

3-Rubens,R.D.; Tinson, C.L.; Coleman, R.E; Knight, R.K.; Tong, D.; Winter, P.J.; North, W.R.(1988): Prednisolone improves the response to primary endocrine treatment for advanced breast cancer. Br. J. Cancer.58: 626-30.

4-Meakin,J.W.; Allt, W.E.; Beale, F. A.; Bush, R. S.; Clark, R. M.; Fitzpatrick, P. J.; Hawkins, N. V.; Jenkin, R. D.; Pringle, J. F.; Reid, J.G.(1983): Ovarian irradiation and prednisone following surgery and radiotherapy for carcinoma of the breast. Breast Cancer Res Treat. 3: s45-8. 
5-Ingle, J. N.; Mailliard, J. A.; Schaid, D. J.; Krook, J. E.; Gesme, D. H. Jr; Windschitl, H. E.; Pfeifle, D. M.; Etzell, P. S.; Gerstner, J. G.; Long, H. J. (1991): A double-blind trial of tamoxifen plus prednisolone versus tamoxifen plus placebo in postmenopausal women with metastatic breast cancer. A collaborative trial of the North Central Cancer Treatment Group and Mayo Clinic. Cancer. 68: 34-9.

6-Fentiman, I. S.; Howell, A.; Hamed, H.; Lee, S. M.; Ranson, M.; Wall, J.; Chaudary, M. A.; Ash, C. M.; Gregory, W. M.; Sellwood, R. (1994): A. A controlled trial of adjuvant tamoxifen, with or without prednisolone, in post-menopausal women with operable breast cancer. Br. J. Cancer. 70(4) p72931.

7-Manni, A. (1989) Endocrine therapy of breast and prostate cancer. Endocrinol. Metab. Clin. North Am. 18:569-92.

8-Hundertmark, S.; Buhler, H.; Rudolf, M.; Weitzel, H. K.; Ragosch, V. (1997): Inhibition of 11 beta-hydroxysteroid dehydrogenase activity enhances the antiproliferative effect of glucocorticosteroids on MCF-7 and ZR-75-1 breast cancer cells. J. Endocrinol. 155: 171-80.

9-Chen, H. J.; Bradley, C. J.; Meites, J. (1976): Stimulation of carcinogen-induced mammary tumor growth in rats by adrenalectomy. Cancer Res. 36: 1414-7.

10-Aylsworth, C. F.; Sylvester, P. W.; Leung, F. C.; Meites, J. (1980): Inhibition of mammary tumor growth by dexamethasone in rats in the presence of high serum prolactin levels. Cancer Res. 40: 1863-6.

11-Welsh, C. W.; Nagasawa, H. (1977): Prolactin and murine mammary tumorigenesis: a review. Cancer Res. 37: 951-63. 


\section{Modulation Of State 5A Activation And 14ET}

12-Matsuzawa, A. (1986): Hormone dependence and independence of mammary tumors in mice. Int. Rev. Cytol. 103: 303-341.

13-Tejwani, G. A.; Gudehithlu, K. P.; Hanissian, S. H.; Gienapp, I. E.; Whitacre, C. C.; Malarkey,W.B. (1991): Facilitation of dimethylbenz[a]anthracene-induced rat mammary tumorigenesis by restraint stress: role of beta-endorphin, prolactin and naltrexone. Carcinogenesis.12: 637-641.

14-Wennbo, H.; Gebre-Medhin, M.; Gritli-Linde, A.; Ohlsson, C.; Isaksson, O. G. P.; Tornell, J. (1997): Activation of the prolactin receptor but not the growth hormone receptor is important for induction of mammary tumors in transgenic mice. J. Clin. Invest., 100: 1-8.

15-Ingram, D. M.; Nottage, E. M.; Roberts, A. N. (1991): Prolactin and breast cancer risk. Med. J. Aust., 153: 469-470.

16-Love, R. R.; Rose, D.R.; Surawicz, T. S.; Newcomb, P. A. (1991): Prolactin and growth hormone levels in premenopausal women with breast cancer and healthy women with a strong family history of breast cancer. Cancer, 68: 1401-5.

17-Maddox, P. R.; Jones, D. L.; Mansel, R. E. (1992): Prolactin and total lactogenic hormone measured by microbioassay and immunoassay in breast cancer. Br. J. Cancer, 65: 456-460.

18-Wang, D. Y.; De Stavola, B. L.; Bulbrook, R. D.; Allen, D. S.; Kwa, H. G.; Fentiman, I. S.; Hayward, J. L.; Millis, R. R. (1992): Relationship of blood prolactin levels and the risk of subsequent breast cancer. Int. J. Epidemiol. 21: 214-221.

19-Zumoff, B. (1994): Hormonal profiles in women with breast cancer. Obstet. Gynecol. Clin. North Am., 21: 751-72. 
20-Nandi, S.; Guzman, R. C.; Yang, J. (1995): Hormones and mammary carcinogenesis in mice, rats and humans: a unifying hypothesis. Proc. Natl. Acad. Sci. 92: 3650-7.

21-Peyrat, J. P.; Venin, P. H.l Bonneterre, J.l Hecquet, B.; Vandewalle, B.; Kelly, P.; Djiane, J. (1984); Effect of bromocriptine treatment on prolactin and steroid receptor levels in human breast cancer. Eur. J. Cancer Clin. Oncol. 20: 1363-7.

22-Bonneterre, J.; Peyrat, J. P.; Beuscart, R.; Demaille, A. (1990): Biological and clinical aspects of prolactin receptors (prolactin-R) in human breast cancer. J. Steroid Biochem. Mol. Biol. 37: 977-981.

23-Fields, K.; Kulig, E.; Lloyd, R. V. (1993): Detection of prolactin messenger RNA in mammary and other normal and neoplastic tissues by polymerase chain reaction. Lab. Invest. 68: 354-360.

24-Clevenger, C. V.; Chang, W. P.; Ngo, W.; Pasha, T. M.; Montone, K. T.; Tomaszewski, J. E. (1995): Expression of prolactin and prolactin receptor in human breast carcinoma: Evidence for an autocrine/paracrine loop. Am. J. Pathol. 146: 695-705.

25-Ginsburg, E.; Vonderhaar, B. K. (1995): Prolactin synthesis and secretion by human breast cancer cells. Cancer Res.55: 25912595 .

26-Mershon, J.; Sall, W.; Mitchner, N.; Ben-Jonathan, N. (1995): Prolactin is a local growth factor in rat mammary tumors. Endocrinology. 136: 3619-23.

27-Fuh, G.; Wells, J. A. (1995): Prolactin receptor antagonists that inhibit the growth of breast cancer cell lines. J. Biol. Chem. 270: 13133-7. 


\section{Modulation Of State 5A Activation And 14ET}

28-Murphy, L. J.; Murphy, L. C.; Vrhovsek, E.; Sutherland, R. L.; Lazarus, L. (1984): Correlation of lactogenic receptor concentration in human breast cancer with estrogen receptor concentration. Cancer Res. 44: 1963-8.

29-Shiu, R. P. (1979): Prolactin receptors in human breast cancer cells in long-term tissue culture. Cancer Res. 39: 4381-6.

30-Shiu, R. P.; Iwasiow, B. M. (1985): Prolactin-inducible proteins in human breast cancer cells. J. Biol. Chem. 260: 1130711313.

31-Manni, A.; Wright, C.; Davis, G.; Glenn, J.; Joehl, R.; Feil, P. (1986): Promotion by prolactin of the growth of human breast neoplasms cultured in vitro in the soft agar clonogenic assay. Cancer Res. 46: 1669-1672.

32-Malarkey, W. B.; Kennedy, M.; Allred, L. E.; Milo, G. (1983): Physiological concentrations of prolactin can promote the growth of human breast tumor cells in culture. J. Clin. Endocrinol. Metab. 56: 673-677.

33-Biswas, R.; Vonderhaar, B. K. (1987): Role of serum in the prolactin responsiveness of MCF-7 human breast cancer cells in long-term tissue culture. Cancer Res. 47: 3509-3514.

34-Juergens, W. G.; Stockdale, F. E.; Topper, Y. J.; Elias, J. J. (1965): Hormone-dependent differentiation of mammary gland in vitro. Proc. Natl. Acad. Sci. 54: 629-34.

35-Borellini, F.; Oka, T. (1989): Growth control and differentiation in mammary epithelial cells. Environ. Health Perspect. 80: 8599.

36-Merlo, G. R.; Graus-Porta, D.; Cella, N.; Marte, B. M.; Taverna, D.; Hynes, N. E. (1996): Growth, differentiation 
and survival of HC11 mammary epithelial cells: diverse effects of receptor tyrosine kinase-activating peptide growth factors. Eur. J. Cell Biol. 70: 97-105.

37-Rui, H.; Kirken, R. A.; Farrar, W. L. (1994): Activation of receptor-associated tyrosine kinase JAK2 by prolactin. J. Biol. Chem. 269: 5364-8.

38-Gouilleux, F.; Wakao, H.; Mundt, M.; Groner, B. (1994): Prolactin induces phosphorylation of Tyr694 of Stat5 (MGF), a prerequisite for DNA binding and induction of transcription. EMBO, 13: 4361-9.

39-Watson, C. J.; Burdon, T. G. (1996): Prolactin signal transduction mechanisms in the mammary gland: the role of the Jak/Stat pathway. Rev. Reprod. 1: 1-5.

40-Erwin, R. A.; Kirken, R. A.; Malabarba, M. G.; Farrar, W. L.; Rui, H. (1995): Prolactin activates Ras via signaling proteins SHC, growth factor receptor bound 2, and son of sevenless. Endocrinology. 136: 3512-8.

41-Das, R.; Vonderhaar, B. K. (1996): Involvement of SHC, GRB2, SOS and RAS in prolactin signal transduction in mammary epithelial cells. Oncogene. 13: 1139-45.

42-Das, R.; Vonderhaar, B. K. (1996): Activation of raf-1, MEK, and MAP kinase in prolactin responsive mammary cells. Breast Cancer Res. Treat. 40: 141-9.

43-Carey, G. B.; Liberti, J. P. (1995): Stimulation of receptorassociated kinase, tyrosine kinase, and MAP kinase is required for prolactin-mediated macromolecular biosynthesis and mitogenesis in Nb2 lymphoma. Arch. Biochem. Biophys. 316: 179-89. 


\section{Modulation Of State 5A Activation And 14ET}

44-Buckley, A. R.; Rao, Y. P.; Buckley, D. J.; Gout, P. W. (1994):

Prolactin-induced phosphorylation and nuclear translocation of MAP kinase in Nb2 lymphoma cells. Biochem. Biophys. Res. Commun. 204: 1158-64.

45-Han, Y.; Watling, D.; Rogers, N. C.; Stark, G. R. (1997): JAK2 and Stat5, but not JAK1 and Stat1, are required for prolactininduced beta-lactoglobulin transcription. Mol. Endocrinol. 11: $1180-8$

46-Groner, B.; Gouilleux, F. (1995): Prolactin-mediated gene activation in mammary epithelial cells. Curr. Opin. Genet. Dev. 5: 587-94.

47-Wartmann, M.; Cella, N.; Hofer, P.; Groner, B.; Liu, X.; Hennighausen, L.; Hynes, N. E. (1996): Lactogenic hormone activation of Stat5 and transcription of the betacasein gene in mammary epithelial cells is independent of p42 ERK2 mitogen-activated protein kinase activity. J. Biol. Chem.271: 31863-8.

48-Liu, X.; Robinson, G. W.; Wagner, K. U.; Garrett, L.; Wynshaw-Boris, A.; Hennighausen, L. (1997): Stat5a is mandatory for adult mammary gland development and lactogenesis. Genes Dev. 11: 179-86.

49-Stocklin, E.; Wissler, M.; Gouilleux, F.; Groner, B. (1996): Functional interactions between Stat5 and the glucocorticoid receptor. Nature. 383: 726-8.

50-Schmitt-Ney, M.; Doppler, W.; Ball, R. K.; Groner, B. (1991): Beta-casein gene promoter activity is regulated by the hormone-mediated relief of transcriptional repression and a mammary-gland-specific nuclear factor. Mol. Cell. Biol.11: $3745-55$. 
51-Stoecklin, E.; Wissler, M.; Moriggl, R.; Groner, B. (1997): Specific DNA binding of Stat5, but not of glucocorticoid receptor, is required for their functional cooperation in the regulation of gene transcription. Mol. Cell. Biol. 17: 6708-16 .

52-Lechner, J.; Welte, T.; Tomasi, J. K.; Bruno, P.; Cairns, C.; Gustafsson, J.; Doppler, W. (1997): Promoter-dependent synergy between glucocorticoid receptor and Stat5 in the activation of beta-casein gene transcription. J. Biol. Chem. 272: 20954-60 .

53-Doppler, W.; Hock, W.; Hofer, P.; Groner, B.; Ball, R. K. (1990): Prolactin and glucocorticoid hormones control transcription of the beta-casein gene by kinetically distinct mechanisms. Mol. Endocrinol. 4: 912-9.

54-Sultan, AS.; Xie, J.; Lebaron, MJ.; et al. (2005): Stat5 promotes homotypic adhesion and inhibits invasive characteristics of human breast cancer cells. Oncogene. 24:746-60.

55-Sultan, AS.; Brim, H.; Sherif, ZA. (2008): Co-overexpression of Janus kinase 2 and

signal transducer and activator of tra,nscription 5a promotes differentiation of mammary cancer cells through reversal of epithelial-mesenchymal transition. Cancer Sci. 2:272.

56-DaSilva, L.; Rui, H.; Erwin, R. A.; Howard, O. M.; Kirken, R. A.; Malabarba, M. G.;

Hackett, R. H.; Larner, A. C.; Farrar, W. L. (1996): Prolactin recruits Stat1, Stat3 and Stat5 independent of conserved receptor tyrosines TYR402, TYR479, TYR515 and TYR580. Mol. Cell. Endocrinol. 117: 131-40.

57-Kirken, R. A.; Malabarba, M. G.; Xu, J.; Liu, X.; Farrar, W. L.; Hennighausen, L.; Larner, A. C.; Grimley, P. M.; Rui, H. (1997): Prolactin stimulates serine/tyrosine phosphorylation 


\section{Modulation Of State 5A Activation And 14ET}

and formation of heterocomplexes of multiple Stat5 isoforms in Nb2 lymphocytes. J. Biol. Chem.272: 14098-103.

58-Laemmli, U. K. (1970): Cleavage of structural proteins during the assembly of the head of bacteriophage T4. Nature. 277: 680688 .

59-Wilson, K. C.; Finbloom, D. S. (1992): Interferon gamma rapidly induces in human monocytes a DNA-binding factor that recognizes the gamma response region within the promoter of the gene for the high-affinity Fc gamma receptor. Proc. Natl. Acad. Sci. 89:11964-11968 .

60-Topper, Y. J.; Freeman, C. S. (1980): Multiple hormone interactions in the developmental biology of the mammary gland. Physiol. Rev.60: 1049-106.

61-Archer, T. K., Zaniewski, E.; Moyer, M. L.; Nordeen, S. K. (1994): The differential capacity of glucocorticoids and progestins to alter chromatin structure and induce gene expression in human breast cancer cells. Mol. Endocrinol.8: 1154-62.

62-Engel, L. W.; Young N. A. (1978): Human breast carcinoma cells in continuous culture: a review. Cancer Res.38: 4327-39.

63-Myal, Y.; Robinson, D. B.; Iwasiow, B.; Tsuyuki, D.; Wong, P.; Shiu, R. P. (1991): The prolactin-inducible protein (PIP/GCDFP-15) gene: cloning, structure and regulation. Mol. Cell. Endocrinol.80: 165-75.

64-Miller, W. R.; Shivas, A. A.; Franchimont, P.; Haagensen, D. E. (1988): Breast gross cystic disease protein 15 in human breast cancer in culture. Eur. J. Cancer Clin. Oncol. 24: 223-8. 
65-Labrie, F.; Poulin, R.; Simard, J.; Zhao, H. F.; Labrie, C.; Dauvois, S.; Dumont, M.,;Hatton, A. C.; Poirier, D.; Merand, Y. (1990): Interactions between estrogens, androgens, progestins, and glucocorticoids in ZR-75-1 human breast cancer cells. Ann. N. Y. Acad. Sci. 595: 130-48, 1990.

66-Bolander, F. F. Jr., Nicholas, K. R., Van Wyk, J. J., Topper, Y. J. (1989): Insulin is essential for accumulation of casein mRNA in mouse mammary epithelial cells. Proc. Natl. Acad. Sci. 78: 5682-4.

67-Schaber, J. D.; Fang, H.; Xu, J.; Grimley, P. M.; Rui, H. (1998): Prolactin Activates Stat1 but does not antagonize Stat1-mediated growth inhibition by type I interferons in human breast cancer cells. Cancer Res.58: 1914-19 .

68-Udy, G. B.; Towers, R. P.; Snell, R. G.; Wilkins, R. J.; Park, S. H.; Ram, P. A.; Waxman, D. J.; Davey, H. W. (1997): Requirement of Stat5b for sexual dimorphism of body growth rates and liver gene expression. Proc. Natl. Acad. Sci.94: 7239-44.

69-Rui, H.; Kirken, R. A.; Malabarba, M. G.; Erwin, R. A.; Schaber, J. D.; Duhé, R.; Larner, A. C.; Farrar, W. L. (2007): Cell-dependent activation of tyrosine kinases Jak1, Jak2 and Tyk2 by prolactin. Mol. Endo. 2: 2218-2232.

70-Kirken,R.A.; Malabarba, M. G.; Xu, J.; DaSilva, L.; Erwin, R. A.; Liu, X.; Hennighausen, L.; Rui,H.; Farrar,W.L. (1997): Two discrete regions of interleukin-2 (IL2) receptor beta independently mediate IL2 activation of a PD98059/rapamycin/wortmannin-insensitive Stat5a/b serine kinase. J. Biol. Chem. 272: 15459-65 .

71-Waxman, D. J.; Ram, P. A.; Park, S. H.; Choi, H. K. (1995): Intermittent plasma growth hormone triggers tyrosine 


\section{Modulation Of State 5A Activation And 14ET}

phosphorylation and nuclear translocation of a liver-expressed, Stat 5-related DNA binding protein. Proposed role as an intracellular regulator of male-specific liver gene transcription. J. Biol. Chem. 270: 13262-70.

72-Ram, P. A.; Park, S. H.; Choi, H. K.; Waxman, D. J. (1996): Growth hormone activation of Stat 1, Stat 3, and Stat 5 in rat liver. Differential kinetics of hormone desensitization and growth hormone stimulation of both tyrosine phosphorylation and serine/threonine phosphorylation. J. Biol. Chem. 271: 5929-40.

73-Darnell, J. E.; Kerr, I. M.; Stark, G. R. (1994): Jak-Stat pathways and transcriptional activation in response to IFNs and other extracellular signaling proteins. Science. 264: 141521 .

74-David, M.; Petricoin, E. F.; Igarashi, K.; Feldman, G. M.; Finbloom, D. S.; Larner, A. C. (1994): Prolactin activates the interferon-regulated p91 transcription factor and the Jak2 kinase by tyrosine phosphorylation. Proc. Natl. Acad. Sci. U.S.A. 91: 7174-8.

75-Doppler, W.; Groner, B.; Ball, R. K. (1989): Prolactin and glucocorticoid hormones synergistically induce expression of transfected rat beta-casein gene promoter constructs in a mammary epithelial cell line. Proc. Natl. Acad. Sci. U.S.A. 86: 104-8.

76-Happ, B.; Groner, B. (1993): The activated mammary gland specific nuclear factor (MGF) enhances in vitro transcription 
of the beta-casein gene promoter. J. Steroid Biochem. Mol. Biol. 47: 21-30.

77-Fuh, G.; Wells, J. A. (1995): Prolactin receptor antagonists that inhibit the growth of breast cancer cell lines. J. Biol. Chem. 270: 13133-7.

78-Shiu, R. P.; Paterson, J. A. (1984): Alteration of cell shape, adhesion, and lipid accumulation in human breast cancer cells (T-47D) by human prolactin and growth hormone. Cancer Res. 44: $1178-1186$.

79-Rosen, J. M.; Humphreys, R.; Krnacik, S.; Juo, P.; Raught, B. (1994): The regulation of mammary gland development by hormones, growth factors, and oncogenes. Prog. Clin. Biol. Res. 387: 95-111.

80-Kalache, A.; Maguire, A.; Thompson, S. G. (1993): Age at last full-term pregnancy and risk of breast cancer. Lancet. 341: 33-36.

81-Schindler, C.; Darnell, J. E. (1995): Transcriptional responses to polypeptide ligands: the Jak-Stat pathway. Ann. Rev. Biochem. 64: 621-51.

82-Teglund, S.; McKay, C.; Schuetz, E.; van Deursen, J. M.; Stravopodis, D.; Wang, D.; Brown, M.; Bodner, S.; Grosveld, G.; Ihle, J. N. (1998): Stat5a and Stat5b proteins have essential and nonessential, or redundant, roles in cytokine responses. Cell. 93: 841-50.

83-Yamashita, H.; Xu, J.; Erwin, RA.; Farrar, WL.; Kirken, RA.; Rui H. (1998) Differential control of the phosphorylation state of proline-juxtaposed serine residues S725 of Stat5a and S730 of Stat5b in prolactin-sensitive cells. J. Biol. Chem. 273: 30218-30224. 


\section{Modulation Of State 5A Activation And 14ET}

84-Lin, J. X.; Mietz, J.; Modi, W. S.; John, S.; Leonard, W.J. (1996): Cloning of human Stat5B. Reconstitution of interleukin-2-induced Stat5A and Stat5B DNA binding activity in COS-7 cells. J. Biol. Chem. 271: 10738-44.

85-Futreal, P. A.; Soderkvist, P.; Marks, J. R.; Iglehart, J. D.; Cochran, C.; Barrett, J. C.; Wiseman, R. W. (1992): Detection of frequent allelic loss on proximal chromosome 17q in sporadic breast carcinoma using microsatellite length polymorphisms. Cancer Res. 52: 2624-7. 